\title{
INTEGRATED PROCESSING TECHNOLOGY OF WASTES FROM CEREAL PRODUCTION
}

\begin{abstract}
The article analyzes the structure of production of cereals in the country, it is established that during the processing of grain into grains a significant part of secondary material resources (flour and husk) is formed. Therefore, it is important to use husk of cereals as raw material for biofuel production.

Different methods of producing organic solid biofuels have been analyzed, and it is shown that there are shortcomings of finished products - briquettes and pellets obtained without the use of binders, one of which is the problem of transportation over long distances, during which a considerable amount of compressed biofuel is destroyed due to an increase in humidity and, consequently, a decrease in their calorific values. Fuel pellets are mainly produced without addition, while for the production of briquettes with improved quality indicators, various additives and binders are used.

The purpose of the work is to substantiate the complex technology of the processing of the waste of grain mills into pressed products. Object and object of research are formulated for achievement of the set goal. The object of research is the technological process of processing of waste of cereal mills, the regimes of certain technological processes, in particular preparation of binders. The subject of research is barley and barley husk, binders (barley glue). The use of starchy raw material - flour is suggested and grounded as a binder. On the basis of experimental studies, it has been proved that the most effective method is to prepare a paste of barley flour with a content of $15 \%$ CP followed by its introduction into biofuels in the amount of 5\%.

The article suggests and substantiates the complex technology of processing of cereal-based waste products into pressed products (fodder mixtures and biofuels), which includes the following technological lines: a pipeline preparation line; line of preparation for the binders; line of preparation of macro components; granulation line; briquetting line. The fuel pellets produced by this technology will have $1.13 \mathrm{~kg} / \mathrm{m}^{3}$, fragility up to $10 \%$.

The scheme of the technological process of complex processing of cereal-based waste products into pressed products is presented. The principal technological scheme for the production of a granulated feed mixture or fuel pellets of feed is a holistic system within which the subsystems $A, B, B, G 1, D$ are interconnected. The principal technological scheme for the production of briquetted biofuels is a holistic system within which interconnections' The subsystems $A, B, B, G, E$ function functioning seamlessly.

Keywords: Secondary raw materials, biofuels, husk, flour, pressing, binder, starch, paste, granules, pellets
\end{abstract}

\section{Introduction}

Cereals are the second largest and most processed product of grain crops. The distinctive features of the cereal production should include a variety of the raw materials and products manufactured from it. In Ukraine, almost all grain crops are grown from which cereals are produced. Therefore, the prospects for the development of the cereal market directly depend on the production and the quality of crops, as well as the availability of grain purveyances.

According to the State statistics service of Ukraine, in 2016 it was harvested and collected by farms 260433,5 thousand tons of wheat, 260433.5 thousand tons, 280746.1 thousand tons of corn, 94357.1 thousand tons of barley, and 4998.9 thousand tons of oats, buckwheat 1764,3 thousand tons, millet 1896,7 thousand tons [1]. In the last ten years, on average, 352 thousand tons of cereals per year were produced in Ukraine. Traditionally, the largest shares in the production structure are buckwheat and corn grits (26 and 18\%), a little less wheat, peas and barley $(14,13$ and $7 \%$, respectively).

Main types of the secondary raw materials of the grain-processing industry are cereal wastes, flour, husk, germ and bran. Their quantity depends on the type and perfection of the technological process at the cereal plant (CP).

Thus, in the grain processing there are following quantities of by-products (on average): of millet - 7.5\% of flour and $15.5 \%$ of husk; wheat - $30 \%$ of flour, from barley - $18 \%$ of flour and pearl barley $40 \%$ flour and $7 \%$ husk, in the processing of buckwheat in cereals - 3.5\% flour and $20.8 \%$ husk, oats - flour $4-16 \%$, and hulls- 26
- $27 \%$, peas - $6 \%$ husk and 6.5 - 26.5 chaff and flour together [2]. Despite the significant amount of their production, the level of use of these secondary raw materials is not high enough. In general, secondary raw materials are used for feeding purposes [3]. However, a significant part of by-products is not used, which is associated with a mismatch of the nutritional value and physical properties of the physiological characteristics of modern animal breeds and poultry crosses. Therefore, the assignment of efficient waste processing, including biofuel, is relevant.

\section{Analysis of literary data and problem statement}

Today in Ukraine, the following documents are used as standards for solid fuels: TY «Pellets», Technological regulations for the production of briquettes and fuel pellets from sunflower husk; TY «Fuel from waste wood, agricultural crops pelleted and briquetted»; GOST 324388. Wood. Specifications; GOST 7657-84. Charcoal. Technical conditions; GOST 23246-78 Grinded wood. Terms and definitions; DSTY 7123:2009 Sunflower husk Specifications; DSTY 7124:2009 Sunflower husk pressed pelleted Technical conditions. From this list it can be seen that these documents regulate only the primary types of raw materials for biofuels - firewood, chopped wood, sawdust, straw, sunflower husk, charcoal, and there are no recommendations for the husks of cereals $[4,5]$.

However, a comparison of the chemical composition of this by-product of grain processing on $\mathrm{CP}$ allows us to conclude that it is close to the chemical composition, the energy value of other raw materials for the production of solid organic biofuels (straw, sunflower

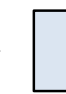


husks, corn kernels and trunks, reeds, leaves, sawdust etc.). Namely, the husk of cereals makes up a certain resource potential for the production of solid organic biofuels, but has several disadvantages: poor flowability, low specific weight and density, as a result - poor transportability, low calorific value. It is clear that the only acceptable form of finished products is pressed (pelleted and briquetted) [6].

The processing of organic matter into biofuels for maximum economic returns is usually carried out by pressing. So, when pelleting of sawdust is assumed, on the recommendation of the company California Pellet Mill, the optimum temperature of the granules from 88 to $102{ }^{\circ} \mathrm{C}$. This is explained by the fact that the melting of lignin, which occurs at $90{ }^{\circ} \mathrm{C}$, and the formation of water vapor, breaks the granule, must be ensured. Pellets, unlike ordinary wood, have a much lower humidity of $8-12 \%$. Such humidity, together with a sufficiently high density of up to $1400 \mathrm{~kg} / \mathrm{m}^{3}$, makes it possible to achieve a calorific value of 14 to $23 \mathrm{MJ} / \mathrm{kg}$. This is more than that of brown coal and peat briquettes [7]. For the production of solid biofuels without the use of binding substances (BS), mainly wood waste and plant biomass with a sufficiently high lignin content are used [8].

Authors [9] thought that agricultural waste (husks, husks, straw etc.) should be used for energy purposes also after pelleting using the same technology as wood waste or peat. For example, the straw is crushed by a hammer mill and after drying is put into the pellet mill. At a moisture content of $14-15 \%$, straw does not require pre-drying. In some cases, to increase the strength of the granules used binders of natural origin (lignin, starch).

Other scientists propose a method for preparing a multicomponent solid biofuel by briquetting [10], which includes feeding plant waste with a moisture content of $4-12 \%$ and a fractional composition of $2-10 \mathrm{~mm}$, pressing, subsequent formation and dividing, while the briquettes are subjected to additional heat treatment, the formation is carried out continuously and simultaneously with heat treatment at a temperature of $150-250^{\circ} \mathrm{C}$, depending on the type of raw material.

This method includes the preloading of the crushed raw material, its weighting and final pelleting, besides the weighting of two components of the mixture of crushed straw and corn cobs, growing in proportions from 1: 1 to 1: 5. This method is carried out as follows: chopped straw is loaded into the hopper of the dispenser, and crushed corn cobs - into the hopper of the dispenser. Dispensers form the flows of the components of the mixture, taking into account their properties, controlled by humidity sensors and mass flow rate of straw and crushed cobs.

The individual process streams thus formed are sent to the bunker of the integrating storage tank of the mixture, where accumulation and mixing of components takes place, followed by feeding the mixture to the press bunker, then pressing the mixture at a temperature of $150^{\circ} \mathrm{C}$ to form briquettes with moisture $14.5-15.5 \%$, calorific value $4400-4500 \mathrm{kcal} / \mathrm{kg}$ and density of 1000 $1100 \mathrm{~kg} / \mathrm{m}^{3}$.

Domestic scientists propose a method for manufacturing environmentally friendly pellets of solid fuel, which are made from crushed wood and other organic raw materials by pressing into cylindrical pellets [11].

Organic raw materials used in well-known pellets, except wood raw materials, are trunks of corn and sunflower, reeds, grass, leaves of trees (in particular, conifers), tobacco production waste, tobacco dust, tobacco cuts, millet stalks, cereal straw and like that

Each type of raw material through its differences in physical properties requires different efforts to grind them, and the resulting biomass has a different density and elasticity, which makes it difficult to keep their fraction in a single design, even after pressing. The pellets manufactured according to a known method have an unstable form, and, as a result of a mechanical action during manipulations with them, are easily destroyed.

A method of obtaining solid organic fuel from sunflower husk [12]. At the same time, it is crushed to particles of 2-8 $\mathrm{mm}$, treated with water or steam to bring it to a moisture content of $11-20 \%$, granulated or briquetted to obtain a density of $800-1300 \mathrm{~kg} / \mathrm{m}^{3}$, cooled, while reducing the humidity to $12 \%$. Then particles less than $3 \mathrm{~mm}$ are sifted out of the granules. The disadvantage of this method is that the grinding of husks to particles of 2 to $6 \mathrm{~mm}$ does not allow to create optimal conditions for the process of briquetting or granulation. Processing of the crushed raw material with water and steam to bring it to a moisture content of $11-20 \%$ is not optimal for granulation. Conducting pelleting or briquetting to obtain its own density of $800 \mathrm{~kg} / \mathrm{m}^{3}$ is impractical because of the high cost of transportation of this product.

So, the production technology of solid organic biofuels in a pressed form includes a number of operations that can be divided into three main stages: preliminary preparation of raw materials; obtaining pellets or briquettes; operations with the finished pelleted product. The raw materials for the production of extruded biofuels vary significantly in particle size, bulk and specific gravity, humidity, strength of particles of the material, chemical composition of raw materials. Therefore, its own technological scheme is developed for each raw material, which can be both simplified and complicated. Pellets are formed without the use of additional binders: the majority of standards in various countries prohibit their use for the manufacture of briquettes (pellets), because they contain strict environmental requirements for emissions (carbon dioxide, sulfur oxides and nitrogen, soot and other toxic gases) during combustion, as well as the amount of ash and its smoothness [13, 14]. However, the German standard for biofuels DIN 51731-1996 "Testing of solid fuels - Compressed untreated wood - Requirements and testing" allows for the inclusion of wallpaper flour or grain starch as an OR in the amount of up to $2 \%$ in the composition of solid biofuels. It is necessary to remember about the shortcomings of briquettes and pellets obtained without using OR: there is a problem of transportation over long distances, during which a significant amount of compressed biofuel is destroyed due to increased humidity and, consequently, its calorific properties decrease [15].

Therefore, in recent times, it is often recommended to use high molecular weight plasticizers - solid organic binders [16], which not only reduce the pressing 
pressure, but also improve the burning parameters of the pellets.

As such binders can be used natural polymer lignin. It is an amorphous substance from light cream to dark brown in color, the molecular weight of soluble lignin is from 1 to 150 thousand, density is $1250-1450$ $\mathrm{kg} / \mathrm{m}^{3}$. It exhibits plastic properties at elevated pressure and temperature, especially in the wet state. Lignins, isolated in various ways, differ in composition and properties both from the product in the native form and from each other [17]. Other authors also show that lignin, a cheap by-product of wood processing, can be mixed with starch and glycerin, giving more durable and elastic materials [18]. In the process of grinding lignin, very fine particles are formed, which provide good adhesion with starch, proteins and their derivatives with the formation of spatial structures, which makes them attractive for use as a binder.

Donghui Lu et al. [20] studied the effect of various binders (rapeseed flour, coffee bean powder, bark, lignin powder, and pine cones) on pressing briquettes from larch and tulip wood sawdust. It is shown that when using lignin as binder, Palin briquettes with high strength characteristics were obtained.

Other scientists to obtain solid organic fuels from plant materials as binders recommend using Lignosulfonate; gelatinized starch, clays, incl. bentonite and silicate, carboxylmethyl cellulose, flour diatomite, salts with alginic acid, molasses, meadows. It is proposed to grind raw materials with a moisture content of 5-20\% to particles of $0.01-15 \mathrm{~mm}$, treat with water with binder added in the amount of $0.01-10 \%$, bring to a moisture content of $6-20 \%$, granulate or grind to obtain a density of $800-1450 \mathrm{~kg} / \mathrm{m}^{3}$. In press mixers, the mixture is adjusted to a moisture content of 6-20\% [20].

The authors of $[21,22]$ studied the effect of starch and gumarabic on the density and calorific value of sawdust briquettes. It was established that briquettes with high calorific value (33.09 MJ / kg) and density (546 kg / m3) were obtained using starch as binder.

Other authors [23] studied the use of glycerol as a binder in pressing wheat straw and obtained briquettes with low ash and high calorific value $(17.9-18.7 \mathrm{MJ} / \mathrm{kg})$ only in the presence of sawdust of softwood. Solid organic fuel was obtained from straw as follows: straw was crushed to particles of $2-8 \mathrm{~mm}$, a sticky substance of organic origin dissolved in water in a ratio of 1:10 -60 was added to the mixer of the granulator, treated with water or steam to bring moisture d $9-17 \%$, granules or briquettes with obtaining their own density of $800-1500$ $\mathrm{kg} / \mathrm{m}^{3}$, cooled with a simultaneous decrease in humidity to $12 \%$, particles less than $3 \mathrm{~mm}$ were sifted out from the granules.

R. B. Tabakaev and others studied the use of rice bran as an binders when briquetting a mixture of rice straw and sawdust [24]. The authors suggested that the density of briquettes increases due to the formation of crosslinking bonds between two plant polymers - lignin and protein. At the same time, at the pressing temperature of $90{ }^{\circ} \mathrm{C}$, the briquettes had sufficient heat of combustion, but low density, which affected their strength. Increasing the pressing temperature to $150{ }^{\circ} \mathrm{C}$ resulted in high-strength briquettes with a calorific value of $18 \mathrm{MJ} /$ $\mathrm{kg}$.

Some authors propose to use carboxyl methylcellulose in the following ratio of components, wt, $\%$ : starch from 4 to 8 or carboxyl methylcellulose from 4 to 8 , water less than 3 , crushed charcoal - another, up to $100 \%$. The use of these binders allowed to increase the density of the fuel briquette from 500 to $900 \mathrm{~kg} / \mathrm{m} 3$ [25].

Philip H. Steel, Venkata K. Penmetsa has been proposed to use solid biofuels for the production of solid biofuels using binders of biooil obtained by pyrolysis of biomass or various types of lignin (kraft - lignin, organosolvent lignin, black liquor lignin, etc.) [26]. As a result of the research, fuel briquettes with increased hydrophobicity and high heat value were obtained.

Thus, the use of natural, environmentally friendly binders allows you to create environmentally friendly briquetted and granulated fuel with high energy intensity, strength and will provide an opportunity to expand the raw material base for its production. However, the main disadvantage of these methods for producing solid biofuels is the use as a food grade OP, which can lead to an increase in their cost.

The purpose of the study is the substantiation of the complex technology of processing waste from cereal production into extruded products.

The object of the research is the technological process of processing waste from cereal plant, modes of individual technological processes, in particular the preparation of binders.

The subject of the research is the flour and husk barley, a binder.

All studies were performed according to standardized methods at the department of grain processing technology and the department of animal feed technology and biofuels.

The solution to the problem of efficient complex processing of waste of cereal plant with obtaining competitive products is associated with the use of various technological methods of processing raw materials and the similarity of pellet production technology and the production technology of granulated animal feed and vitamin grass meal [27]. After analyzing the known methods of processing such secondary raw materials, it was proposed to use the pressing process (granulation and briquetting) of by-products of the cereal plant, namely, husks (when processing into biofuel) or a multicomponent mixture (in the production of feed mixtures). But, the technology being developed requires some clarification. The latter is associated with the unsatisfactory ability of the husks of cereals to granulate. Therefore, it is proposed to add an OR to the granules. The choice of binder is the most important. The bender must be easy to pelleting, good ability to mix with other components, close to other components of the mixture, flowability, physical and chemical stability and compatibility with other substances of the mixture, a satisfactory price.

Taking into account the above, to ensure the strength of the granules, we consider it advisable to reduce the plasticity of waste of cereal crops (husks) in the process of pressing the binders based on flour, in

\section{$\square$}


particular barley. The ability of the binder torment is due to the content of starch in them, which is gelatinized at high temperatures. The characteristics of their gelatinization determine the structure and properties of natural starch. The thermodynamic melting parameters of rye, wheat, and barley starch, which have a bimodal grain size distribution, are a function of grain size and the number of amylose walk-through chains located in crystalline lamellae [28]. An increase in the mass fraction of amylose and lipids in the grains leads to an increase in melting enthalpy, which indicates a rather close relationship between the melting characteristics of crystalline lamellae and the rheological properties of the starch and the possibility of establishing quantitative patterns between these bonds.

Native starches, when used for food and technical purposes, are usually heat treated with water. Changes in the structure of starch grains occur in this process, which depend on the characteristic features of the type of starch and, accordingly, starchiness. When the temperature of water starch suspensions increases by more than $+30^{\circ} \mathrm{C}$, the hydrogen bonds of molecules in the starch grain partially break, changing its microstructure. In this case, there is a sharp increase in the hydration of amylose and amylopectin, and, consequently, the grain size increases. When the temperature rises, part of amylose diffuses from the amorphous part of the grains and goes into solution, while amylopectin remains mostly in an undissolved state. In the course of the destruction of the grains, the destruction of the crystalline part of the grains begins, the polysaccharides go into solution, and the process of gelatinization occurs. During the processes of swelling and gelatinization, changes in the viscosity of the suspension occur, moreover, they proceed differently for different types of starch. For example, for high-amylose and large grains of all types of starches, these processes proceed faster than for small ones. The lowest initial temperature of gelatinization is in barley and rye starch, and the highest in corn and rice. Gelatinization of amylopectin starch (concentration $4 \%$ ) is characterized by a lower viscosity peak at a temperature of $+95^{\circ} \mathrm{C}$ than, for example, in potato. Barley as well as wheat and corn with low amylose levels show lower gluing temperature and higher stickiness of hot paste, swelling intensity, granular fragility and stability during repeated freezing than starches with a higher amylose content. Heating the paste leads to a decrease in viscosity, but when cooled and the next mixing, it stabilizes. The viscosity of the paste increases due to the strong swelling of amylopectin, which does not dissolve, while amylose dissolves. Gelatinization mass of starch is a spatial grid formed from branched chains of swollen amylopectin, the cells of which are filled with amylose solution. The temperature at which the starch paste acquires the highest viscosity is called gelatinization temperature (for barley it is $+60-80^{\circ} \mathrm{C}$ ). The temperature of gelatinization of starch is influenced by the composition of the medium: the presence of neutral salts and alkalis reduces the temperature of gelatinization, the presence of sugar increases.

Gelatinization of the starch is manifested when it is heated in water, and this ability of its starch is due to the presence of amylopectin in it. In the first phase of heating, water is slowly and back absorbed by the grains of starch, and their limited swelling occurs. The second phase is characterized by the fact that the grains quickly swell, increasing many times, absorbing a large amount of moisture and quickly losing birefringence, that is, their crystalline structure. At the same time, the viscosity of the starch suspension is rapidly growing, and a small amount of starch is dissolved in water. In the third phase of swelling, which occurs at elevated temperatures, the grains become almost shapeless sacks, from which the most soluble part of the starch is washed out. As a rule, large starch grains are gelatinized at a lower temperature than fine ones [28]

The temperature of gelatinization depends mainly on the nature of the starch, the size of the granules, the presence of salts in the water and other factors. Since in some starches there are granules of different sizes, it is correct to speak not about the point of gelatinization, but about its temperature range. The temperature of gelatinization of wheat starch is +54 $62^{\circ} \mathrm{C}$, rye $+50-55^{\circ} \mathrm{C}$, barley $+60-80^{\circ} \mathrm{C}$, corn $+65-$ $75^{\circ} \mathrm{C}$, potato $+59-64^{\circ} \mathrm{C}$.

When a starch slurry is heated in water at a temperature of $35-45^{\circ} \mathrm{C}$, its viscosity somewhat decreases due to a decrease in the viscosity of water, with a further increase in temperature - it grows very slowly, at 75-85 ${ }^{\circ} \mathrm{C}$ it rises sharply, reaches a maximum at $90^{\circ} \mathrm{C}$, and more high temperatures drastically reduced. A sharp increase in viscosity is caused by intense swelling and the onset of gelatinization, mainly of large starch granules. At $90^{\circ} \mathrm{C}$ gelatinization almost ends, the viscosity no longer increases. Its decrease is associated with the destruction of the three-dimensional mesh of the paste as a result of rising temperatures and mechanical agitation. The maximum viscosity depends on the type of starch, the concentration of its suspension and the rate of temperature increase.

So, the process of producing paste is a complex physico-chemical process that depends on many factors, and above all on the size of the particles from which the paste is brewed, and their concentration in the binder. In order to clarify the composition, technology and modes of binder obtaining, a number of relevant laboratory studies have been carried out [6]. For experimental studies of the quality and composition of the binder, a barley flour with a moisture content of $12 \%$, which is also a short circuit waste, was chosen as the source of starch. Due to the cheapness and the presence of excess amounts in the enterprise; the particle size is the passage of sieve № 25 $(120 \div 130$ microns $)$.

Their model mixtures (suspensions) with different dry matter content $(5,10,15 \%$ barley flour) were compiled and their quality was investigated depending on the composition. These model mixtures are poured with the appropriate amount of cold water and brought to a boil to ensure stable irreversible gelatin starch gelatinization, that is, when the solution is proof, the corresponding starch temperature range is $+60 \ldots 80{ }^{\circ} \mathrm{C}$. In the obtained samples of model mixtures, the viscosity is determined, which is directly proportional to the dry matter concentration in the paste. An increase in the dry matter concentration in the binder of more than $15 \%$ is imprac- 
tical because the viscosity increases significantly, which is a negative phenomenon, since it will be difficult to introduce such binder into the press through the nozzles and evenly distribute it in the dry product.

Analysis of the results of experimental studies indicates the feasibility of using a paste with a dry matter content of $15 \%$ and a rational input rate of $5 \%$ OR, since it provides the best indicators of the quality of biofuel granules.

In order to study the rational norm of introducing splicing substances within the specified limits (up to $10 \%$ ), model mixtures were also composed with the content of spicy substances 3, 5, 10\% (the content of barley meal in the binder is $15 \%$ ) and is granulated under the conditions: pressure $-200 \mathrm{~kg} / \mathrm{m}^{2}$, duration 5 minutes, matrix temperature $+80-90{ }^{\circ} \mathrm{C}$; control experience - without adding the substance. In the granules defined quality indicators (table. 1). Analysis of the obtained data allows us to conclude that the optimal content of pollutants in the granules is $5 \%$, since this indicator corresponds to the minimum value of their fragility and the highest density.

Table 1 - Qualitative parameters of the granules during adding binders $15 \% \mathrm{CP}(\mathrm{n}=3)$

\begin{tabular}{|c||c||c||c||c|}
\hline $\begin{array}{c}\text { Binders, } \\
\%\end{array}$ & $\begin{array}{c}\text { Length, } \\
\mathrm{mm}\end{array}$ & $\begin{array}{c}\text { Diameter } \\
, \mathrm{mm}\end{array}$ & $\begin{array}{c}\text { Density, } \\
\mathrm{kg} / \mathrm{m}^{3}\end{array}$ & $\begin{array}{c}\text { Durability, } \\
\%\end{array}$ \\
\hline \hline 3 & 18 & 19 & 1040 & 13,8 \\
\hline \hline 5 & 15 & 19 & 1130 & 9,3 \\
\hline \hline 10 & 19 & 19 & 990 & 8,0 \\
\hline \hline 0 & 13 & 19 & 450 & 60,5 \\
\hline
\end{tabular}

Based on the review of literature and patent sources, as well as a series of experimental studies, we propose the following flow chart (Fig. 1) of an integrated technology for processing short-circuit cereal plant's waste into extruded products, which includes the following process lines: a torment preparation line; PR training line; line for preparation of macro-components; pelleting line; briquetting line.

The basic scheme of complex technology for processing short-circuit waste is presented as an integral system, within which separate subsystems A, B, C, D, G are allocated, whose operation is aimed at obtaining the final result of the system - the release of resource-saving products.

Within the framework of subsystem A, the appropriate raw materials (flour) and the order of operations with it are determined: purification from all types of impurities, as well as its fractionation. The torment is cleaned from metal-magnetic impurities on a magnetic separator, then sieved through a sifter to fractionate the marches and remove accidental impurities. The coarse fraction of the purified meal is sent to the corresponding subsystem $\mathrm{C}$ for the preparation of macrocomponents, and the small fraction of the meal (passage of the sieve No. 025) is dosed into the dispenser and sent to the subsystem B (into the composition of binders).

In subsystems $B$, the raw materials (water, fine fraction of the flour) and the order of operations with it are determined. Water is cleared of accidental impurities, dosed and heated. From subsystem A, a weighted fine fraction of the meal is fed and fed to a special apparatus. The apparatus for brewing the paste consists of a brewing chamber and a starch suspension preparation chamber, a hot water tank and a dosing pump for feeding the starch suspension into the mixer. The brewing chamber is included in the heating shirt. A shaft passes through the steam chamber and the starch suspension preparation chamber. In the zone of preparation of starch suspension, a turbine of the agitator is fixed on the shaft; the walls of the chamber have fins preventing the formation of a funnel. The camera has a device to maintain a constant level of suspension, which automatically adjusts the ratio looks and remains in the paste chamber.

Within subsystem $\mathrm{C}$, the appropriate raw materials (husks, bran, grain wastes I, II cat.) and the procedure for conducting operations with it are determined. The subsystem is implemented by dosing in the ratio stipulated by the corresponding recipe other types of raw materials for the production of feed mixtures and / or solid organic biofuels of the combined composition), mixing them to achieve a homogeneous mass, cleaning from all types of impurities. The technological process on the line of preparation of a portion of macrocomponents is as follows: husk, flour, other types of raw materials enter operational bins, then sent to a dosing unit, where necessary portions are solved, a mixer, a screening device to remove incidental impurities and fed to a magnetic separator, where it is cleaned from metals impurities.

Subsystem $\mathrm{E}$ is implemented by mixing the portion of macro-components obtained on subsystem $\mathrm{C}$ with prepared binder prepared on subsystem $B$, and its general preparation for recycling with the aim of maximum energy saving. For this purpose, a batch technology is provided in the system of a batch of husks - flour-branbinder and co-grinding in special grinding equipment to a particle size of up to $2 \mathrm{~mm}$ to ensure optimal pressing conditions. The technological process on the line of preparation of a portion of macrocomponents is as follows: the purified portion of macrocomponents is fed into the bunker, where it is mixed with the prepared and prepared binder suspension, then fed to the crusher, in which the mixture is crushed to the required size, and from there the crushed mixture is sent for pressing to the appropriate subsystem E.

Subsystem E1 is implemented by grinding a portion of the components prepared on subsystem $\mathrm{C}$ to the required dimensions, and from there the ground mixture is sent for pressing to the corresponding subsystem F.

Subsystem D provides for the manufacture of products prepared on subsystem $\mathrm{G}$, in granular form, for which it is intended granulation, cooling and fractionation. To do this, the mixture is prepared for granulation through a hopper and fed into a pelleting press, granules come out from there, which need to be cooled and therefore the granules pass through the countercurrent chill, then the granules are sieved through the sieve granules and east the granules are sent to the packaging; passage non-pressing pellets are returned to the above-press bunker. 


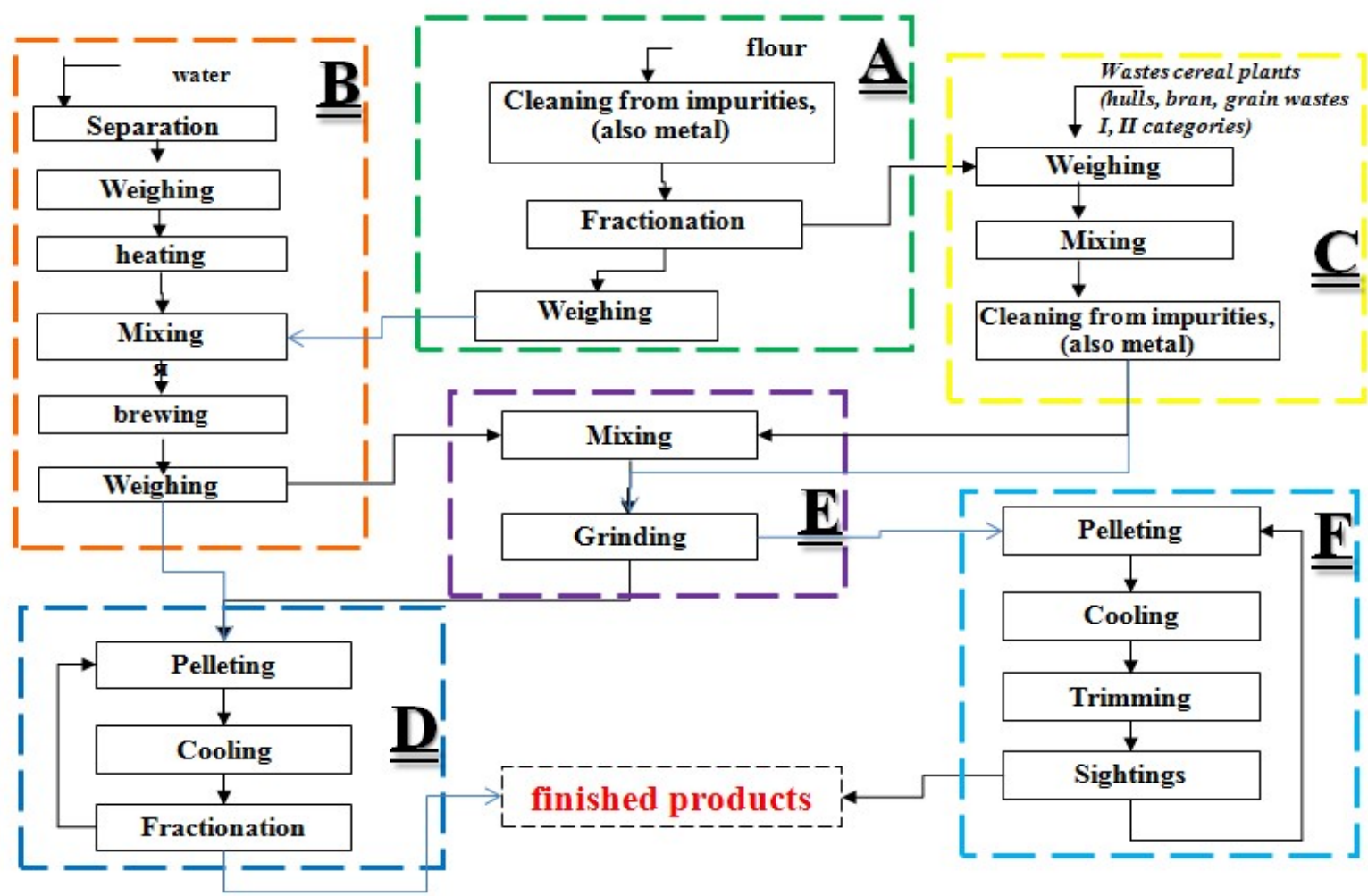

Figure 1 - Schematic diagram of the integrated technology of processing waste of groats in pelleted products

Subsystem F provides for the production of briquettes, for which purpose it is envisaged briquetting, cooling, turning and sizing for the selection of nonstandard briquettes. For this purpose, prepared on the subsystem D, the crushed mixture enters the hopper, which feeds the mixture into press briquettes; press briquettes, briquettes go to the cooler, where they are cooled and further into the molding device, where the briquettes are cut to the necessary sizes, separated from the unpackaged mass. Ready-made briquettes of the NESTRO standard stand for a while and form on pallets.
The basic technological scheme for the production of granulated feed mixture or fuel pellets is an integral system in which the subsystems A, B, C, E, D are interconnected. The basic technological scheme for the production of briquetted biofuels is an integral system within which it is interconnected functioning subsystems $\mathrm{A}, \mathrm{B}, \mathrm{C}, \mathrm{F}, \mathrm{E}$.

Thus, as a result of the work, a comprehensive technology has been proposed and scientifically substantiated for the processing of waste from cereal production into pelleted products.

\section{REFERENCES}

1. Sayt derzhavnogo komitetu statistiki Ukrayini [State Committee of Statistics of Ukraine. Official site] (2014). Elektronniy resurs. Rezhim dostupu: http://www. ukrstat. gov. ua

2. The rules for organizing and maintaining the technological process at the cereals factories. - K., 1998. - 164 p.

3. Globenko, G.O. Technological bases of production of fodder mixtures and their economic expediency in the management of resource conservation / G.O. Globenko, M.O. Svirin // Construction, production and operation of agricultural machines: general. in between Sci.-Tech. save - Kirovograd: KNTU, 2006. - Vip. 36. - P. 101-102.

4. Kolomiychenko M. Economic justification of the feasibility of transition to heating solid biofuels. Harmonization of Ukrainian standards and EU standards: manual // Ukrainian Pellet Union. - 2014 - 47 p.

5. Areas of development of alternative energy sources: emphasis on solid biofuels and flexible technologies for its production: monograph / O. S. Polyansky, O. V. Dyakonov, O. S. Skrypnyk and others. [general edited by VI Dyakonov]; Kharkiv National University of Urban Economics of O. M. Beketov. - Kharkiv: KhNUUE of O. M. Beketov, 2017. - 136 .

6. Khorenzhy N.V. and others. Justification of expediency of use waste cereal production as raw material for biofuel // Scientific works ONAFT. - 2017. - Vol. 81. - No. 1. - p. 27 - 33.

7. Stolarski M. J., Szczukowski S., Tworkowski J. Comparison of quality and production cost of briquettes made from agricultural and forest origin biomass // Renewable energy. 2013. Vol. 57. P. 20-26.

8. Patent of the Russian Federation № 2413755 "Fuel element - briquette, pellet" (C1) IPC C10L5/10 / Kormilitsyn VI, Petrov A.V., Lobko V.P.; claimed. 24.02.2010; publ. 10.03.2011; Bul. № 7. - 8 p.(in Russ.) [Patent Rosciyskoy Federatsii № 2413755 «Toplivniy element - briket, granula» MPK C10L5/10/ Kormilitsyn VI, Petrov A.V., Lobko VP, zayavl. 24.02.2010, opublik. 20.08.2009, Byul. № 23. - 8 s.]

9. Baskov VN, Kolos VA, Sapyan Yu. N. Biofuel from plant raw materials: production, consumption, energy efficiency // Agricultural machines and technologies. - 2010. - No. 6. - P. 13-18.

10. Patent of the Russian Federation № 2364617 "Method for producing briquettes and an installation for manufacturing briquettes" IPC C10L5 / 00, B30B9 / 12, B30B11 / 24, B27N3 / 28 / Pyshechkin AN, Konyashin S.V.; claimed. 01/03/2007; 
publ. 20.08.2009, Bul. № 23. - 8 p. (in Ukr.) [Patent Rosciyskoy Federatsii № 2364617 «Sposob polucheniya briketov $i$ ustanovka dlya izgotovleniya briketov» MPK C10L5/00, B30B9/12, B30B11/24, B27N3/28, / Pyshechkin AN, Konyashin SV; zayavl. 01.03.2007; opublik. 20.08.2009, Byul. № 23. - 8 s.]

11. The patent of Ukraine for the utility model № 69475 "Ecologically clean solid fuel pellets" IPC C10L5/00/ Khomenko V.G.; claimed. 16.11.2011, publ. 25.04.2012, Bul. № 8. - 2 p. (in Ukr.) [Patent Ukrayini na korisnu model № 69475 "EkologIchno chistI peleti tverdogo paliva" MPK C10L5/00/zayavl 16/11/2011, opublik. 25.04.2012, Byul. № 8. - 2 s.]

12. Declarative Patent of Ukraine for Utility Model №. 5426 "Method for obtaining solid organic fuel from sunflower husk" IPC C10L5 / 40 / Kolisnichenko O.M., Klymenko O.G.; published. 15.03.2005, Bul. №. 3. - 2 p. (in Ukr.) [Deklaratsiinyi patent Ukrainy na korysnu model № 5426 «Sposib otrymannia tverdoho orhanichnoho palyva z luzghy soniashnyka» MPK C10L5/40/Kolisnichenko O.M., Klymenko O. H. ; opubl. 15.03.2005, Biul. № 3. - 2 s.]

13. Tumanov, Yu., Underwater Stones of Bioenergetics, Lesprominform, 2005, no. 3. - P. 54-56. (in Russ.)

14. Zotova EV, Safonov AO, Platonov AD Analytical study of the parameters determining the technology of wood pellet production // Lesotekhnichesky Zhurnal. - 2014. - Vol. 4. - No. 1 (13) .- pp. 127 - 132. (in Russ.)

15. Galyavetdinova N.R., Nasybullina A.F. Development of technology for production of wood pellets with improved energy efficiency // Actual research trends of the XXI century: Theory and Practice. 2014. Vol. 2, № 3-4 (8-4). P 27-31. (in Russ.)

16. Myasoedova V. Compositions for pellets and briquettes // The Bioenergy International. Russia, 2007, №3. - P. 6-7. (in Russ.)

17. Homonai M.V. Production of fuel briquettes. Wood raw materials, equipment, technologies, modes of operation: monograph. - Moscow: GOU VPO MGUL, 2006. - 68 p. (in Russ.)

18. Tarasov D., Shahi Ch., Leitch M. Effect of additives on wood pellet physical and thermal characteristics: Reviw // ISRN Forestry. Vol. 2013, Article ID 876939, 6 p. [electronic resource] http:// dx.doi.org/10.1155/2013/876939.

19. Sotannde O.A., Oluyege A.O., Abah G.B. Physical and combustion properties of briquettes from sawdust of Azadirachta indica // Journal of Forestry research. 2010. N 21(1). P. 63 - 67.

20. Declarative Patent of Ukraine for Utility Model № 16994 "Method for obtaining solid organic fuel from raw materials of plant origin" of the IPC (2006) C10L 5/40 / Zaets Yu. O., Gidlyvo V. S., Nekoz S. O., claimed 11/01/2006 , publ. 15.09.2006, Bul. No. 9 - 3 p. (in Ukr.) [Deklaratsiinyi Patent Ukrainy na korysnu model № 16994 «Sposib otrymannia tverdoho orhanichnoho palyva z syrovyny roslynnoho pokhodzhennia» MPK (2006) C10L 5/40 / Zaiets Yu. O., Hostylo V. S., Nekoz S. O. zaiavl.11.01.2006, opubl. 15.09.2006, Biul. №9. - 3 s.]

21. Donghui Lu, Tabil Lope G., Wang D., Wang G. Experimental trials to make wheat straw pellets with wood residue and binders // Biomass and Bioenergy. 2014. Vol. 69. P. 287-296.

22. Chuen-Shii Chou, Sheau-Horng Lin, Wen-Chung Lu Preparation and characterization of solid biomass fuel made rice straw and rice bran // Fuel Processing Technology. 2009. Vol. 90. P. 980-987.

23. Mustelier N.L., Almeida M.E., Cavalheiro J., et.al. Evaluation of pellets produced with undergrowth to be used as biofuels // Waste Biomass Valor. 2012. Vol. 3. P. 285-294.

24. Patent of the Russian Federation No. 2484125 Method for manufacturing fuel briquettes from biomass (C1) IPC C10L5/ 44, C10L5 / 14, C10F7 / 06. / Tabakaev R.B., Zavorin A.S., Kazakov A.V., Plakhova T.M.; claimed. 16.04.2012; publ. 10.06. 2013. Bul. № 16. - 7 p. (in Russ.) [Patent Rossiyskoy Federatsii № 2484125 Sposob izgotovleniya toplivnykh briketov iz biomassy (C1) MPK S10L5/44, C10L5/14, C10F7/06. / Tabakayev R. B., Zavorin A. S., Kazakov A. V., Plakhova T. M.; zayavl. 16.04.2012; opubl. 10.06. 2013. Byul. № 16. - 7 s.]

25. Pat. WO 2011062488 A1 IPC C10L5/44 Fuels pellets, their preparation and use / Meneva B.V., Renirie J.G., Van Der Meijden J. A. A., Van Soest J. J.G., Plijter J.J.; publ. 26.05.2011.

26. Pat. US 20130031830 (A1) IPC C10L11/06; C10L5/04 Method for producing binders and combustible composite materials and composition produced therefrom / Philip H. Steel, Venkata K. Penmetsa; publ. 07.02.2013.

27. Borisov Yu. European quality // Lesprominform, 2004, №9. - P. 86-87. (in Russ.)

28. Donya, D.V. Engineering rheology: a study guide. /D.B. Donya, A.A. Leonov. - Kemerovo: Kemerovo Technological Institute of Food Industry. - 2008. - 123 p. (in Russ.)

УДК [664.762:[631.576.4:66.068]:662.7:57]

Н. В. ХОРЕНЖИЙ, канд. техн. наук, доцент,

А.П. ЛАПІНСЬКА, канд. техн. наук, доцент КОМПЛЕКСНА ТЕХНОЛОГІЯ ПЕРЕРОБКИ ВІДХОДІВ КРУП'ЯНОГО ВИРОБНИЦТВА

\section{Анотація}

В статті проаналізовано структуру виробництва круп в Украйні, встановлено, щуо при переробці зерна в крупу утворюється значна частина вторинних матеріальних ресурсів (мучок та лузги), тому актуальним $\epsilon$ використання лузги круп'яних культур у якості сировини для виробництва біопалива.

Проаналізовано різні способи виробництва твердого органічного біопалива, показано, щчо існують $i$ недоліки готової продукиї - брикетів і пелет, отриманих без використання зв 'язуючих речовин, одним з яких $\epsilon$ проблема транспортування на великі відстані, в ході якого відбувається руйнування значної кількості пресованого біопалива за рахунок підвищення волоGOSTi $i$, як наслідок, зниження їх теплотворних властивостей. Паливні гранули (пелети), в основному, виробляються без додавання зв'язуючих речовин, в той час як для отримання брикетів з поліпшеними показниками якості використовуються різні добавки $і$ зв'язуючі речовини.

Метою роботи є обтрунтування комплексної технологї переробки відходів круп'яного виробництва у пресовані продукти. Для досягнення поставленої мети сформульовані об'єкт та предмет дослідження. 
Об'єктом дослідження є технологічний проиес переробки відходів круп'яних заводів, режими окремих технологічних процесів, зокрема підготовки зв'язуючої речовини (ЗР). Предмет дослідження - мучка та лузга ячмінна, ЗР (ячмінний клейстер). Запропоновано та обгрунтовано у якості ЗР використовувати крохмалевмісну сировину -мучку.

На основі експериментальних досліджень доведено, що найбільи ефективним способом є приготування клейстеру з ячмінної мучки з вмістом сухих речовин $15 \%$ п подальшим його введенням до складу біопалива у кількості 5 \%. У статті запропоновано та обгрунтовано комплексну технологію переробки відходів круп'яного виробництва у пресовані продукти (кормові суміші та біопаливо), яка включає в себе наступні технологічні лінії: лінія підготовки мучки; лінія підготовки ЗР; лінія підготовки макрокомпонентів; лінія гранулювання; лінія брикетування. Отримані за иією технологією паливні пелети будуть мати щільність 1,13 m/м3, крихкість до $10 \%$. Наведена схема технологічного процесу комплексної переробки відходів круп'яного виробництва в пресовані продукти. Принципова технологічна схема одержання гранульованої кормової сумімі або паливних пелет комбікорму представляє собою иілісну систему, в межах якої взаємопов'язано функиіонують підсистеми $A, Б, B, \Gamma 1$, Д.

Ключові слова: вторинні сировинні ресурси, біопаливо, лузга, мучка, пресування, зв'язуюча речовина, крохмаль, клейстер, гранули, пелети

\section{ЛІТЕРАТУР}

1. Державний комітет статистики Украӥни. Офіиійний сайт. [Електроний ресурс] // Режим доступу: http://www.ukrstat.gov.ual

2. Правила організації і ведення технологічного процесу на круп'яних заводах. - К., 1998. - 164 c.

3. Глобенко, Г. О. Технологічні основи виробництва кормових сумішей і їх економічна дочільність в управлінні ресурсозбереженням / Г. О. Глобенко, М. О. Свірень // Конструювання, виробництво та експлуатація сільськогосподарських машин: загальнодерж. міжвід. наук.-техн. зб. - Кіровоград: КНТУ, 2006. - Вип. 36. - С. 101-102.

4. Коломійченко М. Економічне обтрунтування доцільності переходу на опалення твердим біопаливом. Гармонізація украйнських стандартів та стандартів СС: посібник//Украӥнський Пелетний Союз. -2014. -47c.

5. Напрями розвитку альтернативних джерел енергї: акиент на твердому біопаливі та гнучких технологіях його виготовлення: монографія / О.С. Полянський, О.В. Дьяконов, О.С. Скрипник та ін. [за заг. ред. В.І.Д'яконова]; Харків. наи. ун-т міськ. госп-ва ім. О.М. Бекетова. - Харків: ХНУМГ ім. О.М. Бекетова, 2017. $-136 c$.

6. Хоренжий Н. В. та ін. Обгрунтування доиільності використання відходів крупяного виробництва як сировини для біопалива //Наукові прачі ОНАХТ. - 2017. - T. 81. - №. 1. - С. $27-33$.

7. Stolarski M. J., Szczukowski S., Tworkowski J. Comparison of quality and production cost of briquettes made from ag ricultural and forest origin biomass // Renewable energy. 2013. Vol. 57. P. 20-26.

8. Патент Российской Федерации № 2413755 «Топливный элемент - брикет, гранула» (C1) MПК C10L5/10/ Кормилицын В.И., Петров А.В, Лобко В.П.; заявл. 24.02.2010; опубл. 10.03.2011; Бюл.№ 7. - 8 с.

9. Басков В. Н., Колос В. А., Сапьян Ю. Н. Биотопливо из растительного сырья: производство, потребление, энергоэффективность //Сельскохозяйственные машины и технологии. - 2010. - №. 6. - С. 13-18.

10. Патент Российской Федерации № 2364617 «Способ получения брикетов и установка для изготовления брикетов» МПК C10L5/00, В30В9/12, В30B11/24, В27N3/28, / Пышечкин А.Н., Коняшин С.В.; заявл. 01.03.2007; опубл. 20.08.2009, Бюл. № 23. -8 c.

11. Патент Украӥни на корисну модель № 69475 "Екологічно чисті пелети твердого палива" МПК C10L5/00/ Хоменко В.Г.; заявл.16.11.2011; опубл. 25.04.2012, Бюл. № 8. - 2 c.

12. Декларачійний патент Украӥни на корисну модель № 5426 «Спосіб отримання твердого органічного палива з лузги соняшника» МПК C10L5/40/ Колісніченко О.М., Клименко О. Г., опубл. .15.03.2005, Бюл. № 3. - 2 с.

13. Туманов Ю. Подводные камни биоэнергетики // Леспроминформ, 2005, №3. - C. 54-56.

14. Зотова Е.В., Сафонов А.О., Платонов А.Д. Аналитическое исследование параметров, определяющих технологию производства древесных пеллет // Лесотехнический журнал. - 2014. - Т. 4. - №. 1 (13).- С. 127 - 132.

15. Галяветдинова Н.Р., Насыбуллина А.Ф. Разработка технологии получения древесных топливных гранул с повышенной энергетической эффективностью // Актуальные на- правления научных исследований ХХІ века: теория и практика. 2014. T.2, № 3-4 (8-4). С. 27-31.

16. Мясоедова В. Композиции для пеллет и брикетов // The BioenergyInternational. Pоссия, 2007, №3. - C. 6-7.

17. Гомонай М.В. Производство топливных брикетов. Древесное сырье, оборудование, технологии, режимы работы: монография. - М.: ГОУ ВПО МГУЛ, 2006. - 68 c.

18. Tarasov D., Shahi Ch., Leitch M. Effect of additives on wood pellet physical and thermal characteristics: Reviw // ISRN Forestry. Vol. 2013, Article ID 876939, 6 p. [electronic resource] http:// dx.doi.org/10.1155/2013/876939.

19. Sotannde O.A., Oluyege A.O., Abah G.B. Physical and combustion properties of briquettes from sawdust of Azadirachta indica // Journal of Forestry research. 2010. N 21(1). P. $63-67$.

20. Декларачійний Патент Украйни на корисну модель № 16994 «Спосіб отримання твердого органічного палива з сировини рослинного походження» МПК (2006) C10L 5/40/ Заєиь Ю. О., GOSTило В. С., Некоз C. О. заявл.11.01.2006, опубл. 15.09.2006, Бюл. №9. - 3 с.

21. Donghui Lu, Tabil Lope G., Wang D., Wang G. Experimental trials to make wheat straw pellets with wood residue and binders // Biomass and Bioenergy. 2014. Vol. 69. P. 287-296.

22. Chuen-Shii Chou, Sheau-Horng Lin, Wen-Chung Lu Preparation and characterization of solid biomass fuel made rice straw and rice bran // Fuel Processing Technology. 2009. Vol. 90. P. 980-987

23. Mustelier N.L., Almeida M.E., Cavalheiro J., et.al. Evaluation of pellets produced with undergrowth to be used as biofuels // Waste Biomass Valor. 2012. Vol. 3. P. 285-294. 
24. Патент Российской Федерации № 2484125 Способ изготовления топливных брикетов из биомассы (С1) МПК C10L5/44, C10L5/14, C10F7/06. / Табакаев Р. Б., Заворин А. С., Казаков А. В., Плахова Т. М.; заявл. 16.04.2012; опубл. 10.06. 2013. Бюл. № 16. -7 c.

25. Pat. WO 2011062488 A1 IPC C10L5/44 Fuels pellets, their preparation and use / Meneva B.V., Renirie J.G., Van Der Meijden J. A. A., Van Soest J. J.G., Plijter J.J.; publ. 26.05.2011.

26. Pat. US 20130031830 (A1) IPC C10L11/06; C10L5/04 Method for producing binders and combustible composite materials and composition produced therefrom / Philip H. Steel, Venkata K. Penmetsa; publ. 07.02.2013.

27. Борисов Ю. Европейское качество // Леспроминформ, 2004, №9. - С. 86-87.

28. Доня, Д.В. Инженерная реология: учебное пособие. / Д.В. Доня, А.А. Леонов. - Кемерово: Кемеровский технологический институт пищевой промышленности. - 2008. - 123 c.

Надійшла 25.10.2018. До друку 02.11.2018. Рецензія 30.10.18

Адреса для переписки:

ОНАХТ, вул. Канатна, 112, м. Одеса, 65039

\title{
USE OF BIOLOGICALLY ACTIVE SUBSTANCES OF THE HYDROLASE CLASS IN COMPOUND FEED FOR PIGS
}

\begin{abstract}
The high efficiency of poultry and pigs is based on high-yielding breeds, balanced high-yielding mixed fodders and appropriate animal holding conditions. Recently, the tendency of increasing the efficiency of the nutritional potential of mixed fodder has become of increasing importance in order to reduce the cost of this factor in the production of livestock products.

The role of the intermediate link between animals and the nutritional potential of feed is borne by enzymes. A few years ago the question about the use of exogenous enzyme preparations in the composition of feed was controversial. But a better understanding of the action of industrial enzymes, as well as more successfully developed enzyme preparations have changed the situation. Enzymes are now widely used in many countries around the world to improve the quality of feed produced on the basis of barley, wheat, wheat and barley, as well as other cereals.

Perspective is the use of enzyme preparations in ration of young pigs in fattening. In our experiments, lysozyme was used to improve the productivity of young pigs. The experiments were carried out at "Iziumsky compound feed plant", Izium district, Kharkiv region and at the farm "Avangard-D" Ltd., Ovidiopolsky district, Odesa region.

It was established that feeding of young pigs of mixed fodder enriched with the enzyme preparation "Lysozyme" prevents the growth of average daily increments, live weight of animals and reduction of feed costs per unit of products.

The lowest feed costs per unit gain of live weight were set in the experimental group, which comprised 4.2 feeds. unit. That is less in comparison with animals of control group I by $7.0 \%$.

The economic efficiency of raising the young from 4 to 8 months of age has shown that the addition of prezime "lysozyme" to the diet of pigs affects the formation of basic expenses and the receipt of net profit per 1 head.

Key words: feeding, pig, productivity, premix, enzyme preparation "Lysozyme".
\end{abstract}

\section{Formulation of the problem}

In the digestive tract, animals and poultry contain specialized hydrolytic enzymes that split various nutrients - starch, sugars, fats and proteins, but almost no enzymes that can digest cellulose and other carbohydrates. Meanwhile, fiber creates walls of plant cells, which are not completely destroyed when crushing fodder.

Proteins and carbohydrates that are inside whole cell membranes are not available for animal enzymes. If, however, the enzymes that hydrolyze cellulose add to the feed, they begin to work in the intestines together with animal enzymes, which will provide access to valuable nutrients that would be worse off if they were lost to the body. In addition, grain of cereals - wheat, barley, oats, rye - contains a large amount of soluble fiber, which is an anti-nutrient factor. Soluble cellulose forms a highdensity gel in the intestines, resulting in a decrease in the activity of the body's own enzymes, complications of absorption, increasing the risk of developing pathogenic microbes. These negative effects can be prevented by adding feed enzymes that destroy soluble fiber, thus lowering the density of the contents of the intestines. It should also be taken into account that in the early stages of development and under stress, normal secretion of digestive enzymes is suppressed. The deficiency of enzyme activity can be prevented by adding feed enzymes [1].

The proposed method of using the enzyme preparation "Lysozyme" is based on increasing the live weight of pigs and young pigs on fattening.

Enzyme preparations are introduced into an organism of animals and are intensively included in biochemical processes, accelerating the process of decomposition of synthesis and assimilation of fodder proteins, fats and carbohydrates into simple easily assimilated forms and thereby increase the digestibility of feed. As a result of intensive processes of absorption of products of decomposition of feed in the body there is a higher synthesis. 